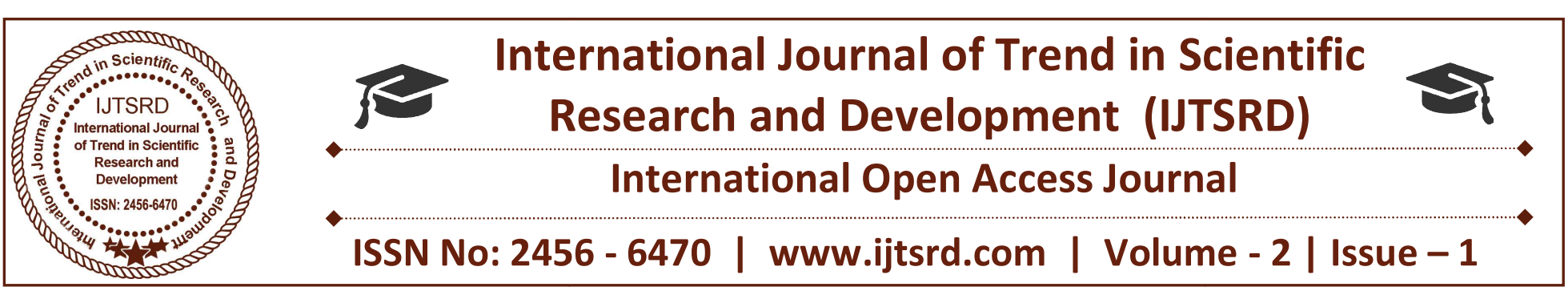

\title{
A Study on the Role of Supplyco Maveli Store in Retailing with Special Reference to Pudukad Gramapanchayath
}

\author{
Mary T. L \\ Department of Commerce, Prajyoti Niketan College, \\ Pudukad, Thrissur, Kerala
}

\section{ABSTRACT}

Retailing in Kerala is subjects too subtle and relevant as Kerala is know of more as a consumer state rather than a producer state. The introduction of Margin Free Markets has turned out to be grand success resulting in it becoming one of the largest retail chains in the country. The Kerala State Civil Supplies Corporation (Supplyco), is a statutory body established in 1974. It procures rice, wheat products, sugar, pulses, vegetables and a range of consumer goods independently from the open market and distributes them through a network of 663 retail outlets called Maveli Stores, 11 supermarkets in district headquarters and 21 mobile Maveli vans operating on designated routes. It is a festival that remembers the golden reign of the legendary King Mahabali, during whose reign Kerala is believed to have prospered. Significantly, the Kerala State Civil Supplies Corporation (Supplyco), through its Maveli chain of retail stores, has contributed to bringing back those golden days by assuring fair price, quality products and insulation against evil trade practices. Maveli offered a new experience to Keralites, which helped it and Supplyco become household names in no time. Quality products and subsidised pricing are the twin advantages that Supplyco extends to the consumer. This study aims to know the role of Supplyco Maveli store in retailing with special reference to Pudukad Gramapanchayath.

Keywords: Retailing, Supplyco, Maveli Store, Organized retailing, Public distribution system

\section{INTRODUCTION}

The Indian Retail Industry is still evolving as an 'Industry', and it has a long way to go. The evolution of the Indian Retail market is quite interesting to be studied. It has its origins in the village weekly markets and meals, the convenience stores, the Khaki stores and the Co-operative stores before graduating to the present day forms of retailing. The retail sector in India can be broadly classified into the formal and the informal retail sectors. The informal retail sector typically consists of small-time retailers with tax evasions and nonconformance to labor laws.

The formal retail sector, which typically consists of large retailers, ensures greater measures of tax enforcements and also a high level of labor usage monitoring. The retail market size in India is estimated to be around $\$ 180$ billion. Retailing provides jobs to almost 15 percent of employable Indian adults and it is perhaps the largest contributor to India's GDP. But the flip side is that the average size of each of the retail outlets in India is only 50 square feet and though a large employer, the industry is very unorganized, fragmented and with a rural bias.

India's status as a good IT hub for outsourcing by U.S. companies has led to young Indians between 20 to 24 years old taking up call center jobs straight out of college. This is a consumer base that typically lives at home, with the family. They have disposable income that is totally discretionary and about 20 to 30 percent higher than prevailing wages. 
International Journal of Trend in Scientific Research and Development (IJTSRD) ISSN: 2456-6470

Maveli Store is a venture of the Kerala State Civil Supplies Corporation (Supplyco).Under the Government programmer of market intervention, pulses and spices are purchased and sold to the consumers at subsidized prices fixed by the Government. The Government of Kerala aids this operation by giving grants every year. The task has been fulfilled through the network of Maveli Store, which was started to commemorate the saga of Mahabali, legendary king of Kerala. Now the Maveli Stores has become a prominent name among the consumers in the state.

Supplyco operates through Maveli Store and Mobile Maveli Store throughout the state covering almost all the Panchayaths. Quality products and subsidized pricing is the twin advantages, which Supplyco extend to the consumer. Supplyco has also undertaken distribution of pulses and spices and other branded products of Civil Supplies Corporation at subsidized prices, through the network of 2000 selected ration shops.

Succumbing to the overwhelming public demand, Supplyco expanded its horizon of activities into other vital areas of consumer interest by starting Super Markets, Petrol Bunks, LPG outlets and Medical Stores (Sabari Medical Stores). Supplyco also markets its own branded products of tea, coffee, milled wheat products, curry products, iodized salt, washing soaps and detergents.

\section{SIGNIFICANCE OF THE STUDY}

Supplyco retail outlets have to compete with margin free market, private supermarkets, and hypermarkets and newly generated organized retailing chains. All these organizations employ modern methods and means of customer satisfaction. These organizations slowly replace the small traders in the unorganized sector and attempt to capture the consumers market in Kerala.

Maveli Store outlets of Supplyco are small in size compared to the firms in the organized private sector. But the preference towards the Supplyco Maveli Stores is not decreasing. The study aims at finding out the role played by the Supplyco in the retail sector.

\section{STATEMENT OF THE PROBLEM}

Consumer market or retail market is market that directly deals with the consumer and here the goods are sold in small quantities. Competition is the retail market has increased much due to the entry of national and multi- national corporate.
But at the same time, the customers were dependent on retail outlets of the Supplyco Ltd. New players in the retail trade compete with one another in saving consumers. The competitors are not only on products and services, but also the price levels and promotional parameters.

The study aims at finding out the role played by the Supplyco in the retail sector of Kerala, in holding the price levels of essential goods along with an assessment of consumer's satisfaction level of Maveli Stores and to recommend measures to strengthen it so as to enable it to compete with other established retailers in Kerala.

\section{OBJECTIVES OF THE STUDY}

The study is to be conducted with the following precise objectives:

To assess the level of satisfaction of the customers of Supplyco Maveli Store.

To examine the objectives and functions of Supplyco Maveli Store.

To identify the major customer groups of Supplyco Maveli Store.

\section{RESEARCH METHODOLOGY}

Primary data collected from the respondents by giving schedules. The sample of 50 customers was selected from the customers of Supplyco Maveli Store in Pudukad. The respondents were selected based on convenience sampling method. Besides this, secondary data collected from Newspapers and official web site of Supplyco. Statistical tools like percentages and averages were used in analyzing the data. For presenting the analyzed data, tables, graphs and diagrams were used.

\section{SCOPE OF STUDY}

The scope of the study was limited to Supplyco Maveli Store in Pudukad, Kerala, India. The Supplyco runs a chain of retail outlets under the name 'Maveli Store' throughout the state covering almost all Panchayaths.

\section{RETAIL MARKETING}

A retailer or retail store is any business enterprise whose sale volume comes primarily from retailing. Any organization selling to final consumers whether it is a manufacturer wholesaler or retailer is doing retailing. It 
International Journal of Trend in Scientific Research and Development (IJTSRD) ISSN: 2456-6470

is the sale of goods and services to the ultimate consumers. Different nations have enjoyed their greatest economic and social progress with a strong and wider retail sector. In India Retail industry is the biggest accounting over $10 \%$ of the country's GDP and responsible for providing $8 \%$ of total employment.

\subsection{Status of Retailing in India}

In India earning of middle class is increasing, the retail sector in the country is bound to come across opportunities like never before till a few years the retail sector in India was more of an organized retailing one with petty vendors dominating the chunk of Industry, but now the scenario has fast been changing. The new retail sector is converting into what we call as organized retailing. To avail this opportunity not only Indian corporate players like Reliance, Tata, ITC have entered into the segment but now more and more foreign players are also showing interest in Indian Retail market.

\subsection{Evolution of Retail in India}

Retailing has become such an intrinsic part of our everyday lives that it often taken for granted. The nation that have enjoyed the greatest economic and social progress have those with a strong retail sector. It is becoming popular as an retail business there is an easier access to a variety of products freedom of choice and higher levels of customer service. The oldest form of retail trade is "Barter System. The history of retail as old as civilization. Retailing is meeting unique needs of Indian due to large size of population with a limited daily or month incomes. While barter is considered to be the oldest form of retail trade, retail in India has evolved to support the unique needs of our country given its size and complexity.

The PDS or the Public Distribution System would easily emerge as the single largest retail chain existing in the country. The evolution of the public distribution of grains in India has its origin in the 'rationing' system introduced by the British during the World War II. The system was started in 1939 in Bombay and subsequently extended to other cities and towns. By the year 1946, as many as 771 cities/towns were covered. The system was abolished post war on attaining Independence, India was forced to reintroduce it in 1950 in the face of renewed inflationary pressures in the economy. A detailed discussion forms a part

The Khadi \& Village Industries (KVIC) was also set up post-independence. Today, there are more than 7,050
KVIC stores across the country. The co-operative movement was again championed by the government, which set up Kendriya Bandar's in 1963. In Maharashtra, Bombay bazaar, which runs stores under the Sahakari Bhandar and Apna Bazaars run a large chain of co-operative stores. With a passage of time concept of multilevel shopping stores with parking facility came in to existence. In1980's retailing in Indian saw a revolutionary change in terms its size and functioning in textile sector retail chain like "S. Kumar's, Bombay Dyeing and Reymonds" came in big way throughout India in the metro cities.

\subsection{State Controlled Retailing}

In the state of Kerala, organized retailing has been growing at a fast rate a private retailing chain like "Spencer's", "Reliance Fresh", "Big Bazaar" etc. In Kerala govt. controlled organized retailers like 'SUPPLYCO' and 'CONSUMERFED' with hundreds of consumer outlets for the distribution of consumer goods at reasonable prices and regulate the price level of essential commodities.

State controlled arrangements for distributing essentials including ration shops under Targeted Public Distribution system (TPDS), retail shops managed by the Kerala State civil supplies corporation Ltd. (SUPPLYCO),retail outlets owned by Kerala state consumer cooperative federation Ltd. Ration shops distribute only a limited number of goods were another shops controlled by govt. provides almost all kinds of essential goods.

Formal PDS in Kerala came into force on first July, 1966 with the implementation of Kerala Rationing Order 1966. The Kerala Rationing Order, 1966 confers the statutory right on every individual to possess a ration card to draw rations with it. The distribution system provides five items such as rice, sugar, wheat and kerosene to every ratio card holders.

\subsection{Kerala State Civil Supplies Corporation}

SUPPLYCO is a govt. of Kerala owned company, founded on 1974, Cochin, India. It acts as the execution arm of the department of food and civil supplies of the govt. of Kerala. The corporation runs a chain of retail supermarkets under the brand name 'SUPPLYCO', and a chain of retail outlets under the name 'Maveli Stores'. It discharges the important responsibilities of public distribution, enforcement of market discipline and promotion of consumer awareness and protection of their interest. The system is evenly spread over the 
International Journal of Trend in Scientific Research and Development (IJTSRD) ISSN: 2456-6470

whole state without any distinction between urban and rural .To ensure equitable distribution of food grain at a fairly low cost to all the especially to the weaker section of the population. There is very good network of wholesale and retail outlet for the distribution of whole state and retail outlet for the distribution of ration article.

The Kerala State Civil Supplies Corporation better known as Supplyco was incorporated in 1974 as a fully owned Government Company with an authorized capital of 15 crores, to meet the limited objectives of regulating the market price of essential commodities. Head quartered in Kochi and operating through 5 Regional offices, 56 depots and around 1200 retail outlets, it has a dedicated work force of nearly 3500 to fulfill the task.

\subsection{Supplyco Maveli Store}

It is a venture of the Kerala state civil supplies corporation under govt. program me of market intervention, pulses and spices are purchased and sold to the consumers at subsidized prices fixed by the govt. The govt. of Kerala aid this operation by giving grand's every year. Task has been fulfilled through the network of Maveli Stores, which was started to commodity the saga of Mahabali legendary king of Kerala. Now the Maveli stores become a prominent name among the consumers in the state. Supply cooperates through Maveli store and mobile Maveli store throughout state covering all the Panchayaths.

Supply co sells essential commodity at subsidized price to the public through the Maveli store .Maveli stores are the prime retail channel owned by the supply co arrest any hike in the open market price of essential commodity. Apart from selling sugar, rice and pulses at subsidized rate, the Maveli store provides a window for purchasing other product at a rate lower than the MRP offered by the companies. Maveli store provides all necessary consumables and cosmetic to the public and play a big role in controlling the open market.

\subsection{Mobile Maveli Store}

The Kerala State Civil Supply Corporation has launched a mobile Maveli store to check the spiraling price off essential commodity. The mobile unit sells goods at a price of $2 \%$ less than that at other supply co outlet. Some traders were leaving price in excess of MRP for packed goods while others were selling out dated commodities .To avoid these taken an action under the provision of the Kerala food stuff order and the packed commodities order. It is a market intervention by government to control prices of essential goods. They aim strengthening of public distribution system.

\subsection{Maveli Labham Store}

Considering the changing consumer behaviors, Supplyco has started a new chain of outlets called Labham Markets. The aim behind introducing Labham Markets is to attract the high and middle-income groups and to spread the reaches of Supplyco to all categories of customers in Kerala. Our first Labham market was inagurated at Peroorkkada in Trivandrum district, in May 2002. The customer response at the Labham Markets is very enterprising.

\section{DATA ANALYSIS}

TABLE - 1: Demographic profile of the respondents

\begin{tabular}{|l|l|l|}
\hline $\begin{array}{l}\text { Demographic } \\
\text { characteristics }\end{array}$ & $\begin{array}{l}\text { No. } \\
\text { respondents }\end{array}$ & percentage \\
\hline
\end{tabular}

\begin{tabular}{|l|l|l|}
\hline Income level & & \\
\hline Below 9000 & 18 & $36 \%$ \\
$9000-18000$ & 6 & $12 \%$ \\
$18000-27000$ & 7 & $14 \%$ \\
$27000-36000$ & 5 & $10 \%$ \\
$36000-45000$ & 7 & $14 \%$ \\
$45000-54000$ & 4 & $8 \%$ \\
Above 54000 & 3 & $6 \%$ \\
\hline Total & 50 & 100 \\
\hline $\begin{array}{l}\text { No. Of family } \\
\text { members }\end{array}$ & 18 & $36 \%$ \\
\hline Up to 4 & 11 & $22 \%$ \\
$4-6$ & 13 & $16 \%$ \\
\hline $6-8$ & 50 & 100 \\
\hline Above 8 & $86 \%$ \\
\hline Total & & \\
\hline
\end{tabular}


International Journal of Trend in Scientific Research and Development (IJTSRD) ISSN: 2456-6470

Table - 1 highlights the demographic profile of the the purchase requirements of the low income group, respondents. The above data reveals that, the majority customers of SupplyCo Maveli Store are below income of 9000. Only $6 \%$ of respondents belongs to high income group, which depends Maveli Stores for the purchases. It was clear that, the Maveli Stores meets than the high income group. It can be interpreted that out of 50 respondents; $36 \%$ of respondents are belongs to nucleus family. $22 \%$ are in the category of 4 to 6 members. $26 \%$ respondent's family number between 6 to 8 . Only $16 \%$ of respondents are in Joint family.

TABLE - 2: Classification of respondents under the categories of APL and BPL

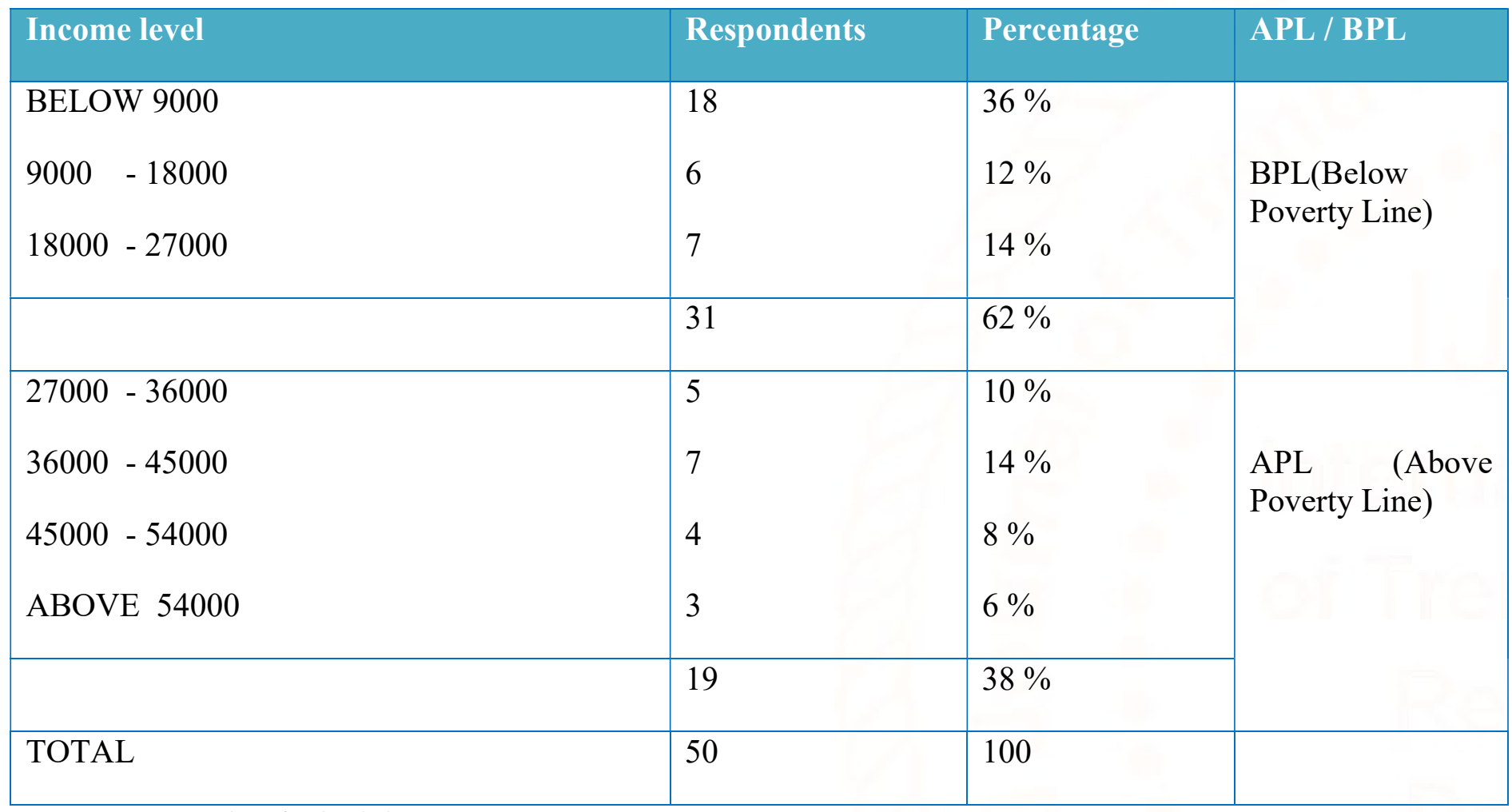

Source:Primary data/Schedules

Table - 2 highlights the people belong to BPL are the major customer groups that depends the Supply co Maveli Stores for purchases. Among the Below Poverty Line category, $36 \%$ are below the income level of 9000 . The major customer group of the selected respondents is belongs to the income group of 9000 .

TABLE - 3: Income level of customers and the frequency of their visit for purchase at Maveli Stores

\begin{tabular}{|c|c|c|c|}
\hline \multirow[b]{2}{*}{ Income level } & \multicolumn{3}{|c|}{ Customer visit frequency for purchase } \\
\hline & Twice in a month & Monthly & Occasionally \\
\hline Below 9000 & $38.52 \%$ & $42.86 \%$ & 0 \\
\hline $9000-18000$ & $16.13 \%$ & $7.14 \%$ & 0 \\
\hline $18000-27000$ & $12.90 \%$ & $21.43 \%$ & 0 \\
\hline $27000-36000$ & $12.90 \%$ & 0 & $20 \%$ \\
\hline $36000-45000$ & $9.6 \%$ & $14.29 \%$ & $40 \%$ \\
\hline $45000-54000$ & $6.45 \%$ & $7.14 \%$ & $20 \%$ \\
\hline Above 54000 & $3.5 \%$ & $7.14 \%$ & $20 \%$ \\
\hline Total & 100 & 100 & 100 \\
\hline
\end{tabular}

Source: Primary data/Schedules 
International Journal of Trend in Scientific Research and Development (IJTSRD) ISSN: 2456-6470

The above table - 3, it can interpret that the customers who are frequently visiting the store is the below income group. Highly income people mostly visiting the store occasionally. It also shows that the respondents under the low income group prefer Maveli Store for their essential requirements.

The table - 6 highlights, there is a relationship between the family size and the rate of purchase. The number of family members' increases then the rate of purchase also increases; purchase rate up to 500 in this category $75 \%$ of customers include in nucleus family group. And it shows about the family size is small, then their requirement for the goods is also small; so they purchasing more subsidized products. When family size increases the respondents shift their purchases from subsidized product to non-subsidized product

TABLE - 7: Income level and their relationship with the stores

\begin{tabular}{|l|l|l|l|l|}
\hline \multicolumn{5}{|l|}{ Relationship with Maveli Stores } \\
\hline INCOME LEVEL & $<3$ year & 3 to 6 years & 6 to 9 years & $>9$ years \\
$9000-18000$ & 0 & 0 & 30 & 51.72 \\
$18000-27000$ & 33.33 & 12.5 & 20 & 10.34 \\
$27000-36000$ & 0 & 25 & 20 & 6.89 \\
$36000-45000$ & 0 & 12.5 & 0 & 13.79 \\
$45000-54000$ & 0 & 25 & 10 & 13.79 \\
ABOVE 54000 & 66.67 & 12.5 & 20 & 3.45 \\
\hline
\end{tabular}

FIGURE - 2: Customers relationship with the Maveli Stores

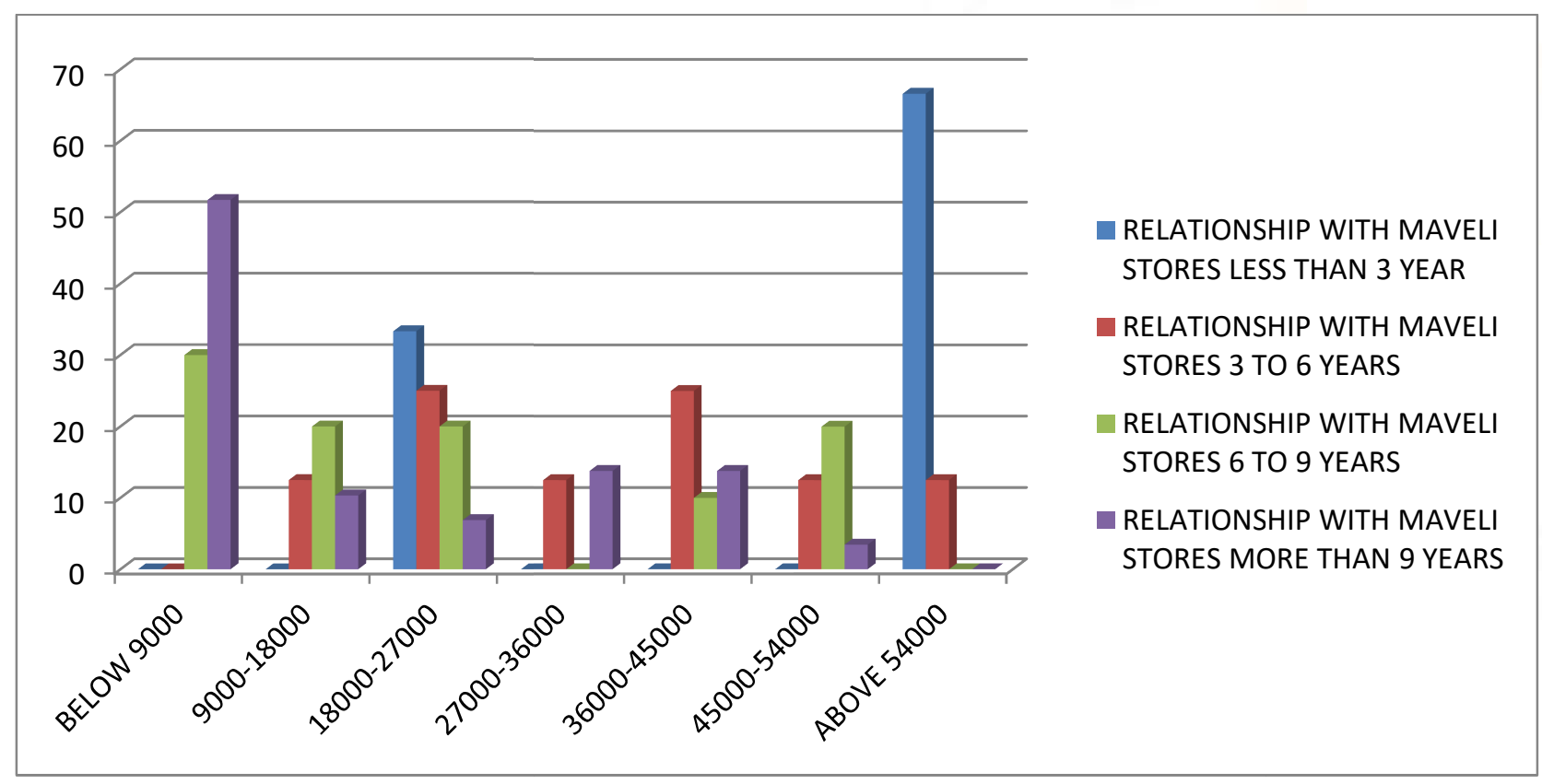

Source: Primary data/Schedules 
International Journal of Trend in Scientific Research and Development (IJTSRD) ISSN: 2456-6470

The table - 7 shows that the relationship between the respondents and the Maveli Store, and normal and oldest customers of the Maveli Store is low income group that is $51.72 \%$, among the respondents. And also the new customers of Maveli Store are majority of the high income group that is $66.67 \%$.

TABLE - 8: Superior features of government controlled retail shops

\begin{tabular}{|l|c|c|}
\hline Features & No. Of respondents & Percentage \% \\
\hline Reasonable/discounted price rate & 28 & $56 \%$ \\
Quality & 10 & $20 \%$ \\
No price hike & 6 & $12 \%$ \\
Availability of essential goods & 6 & $12 \%$ \\
\hline Total & 50 & 100 \\
\hline
\end{tabular}

FIGURE - 3: Superior features of Supplyco Maveli Stores

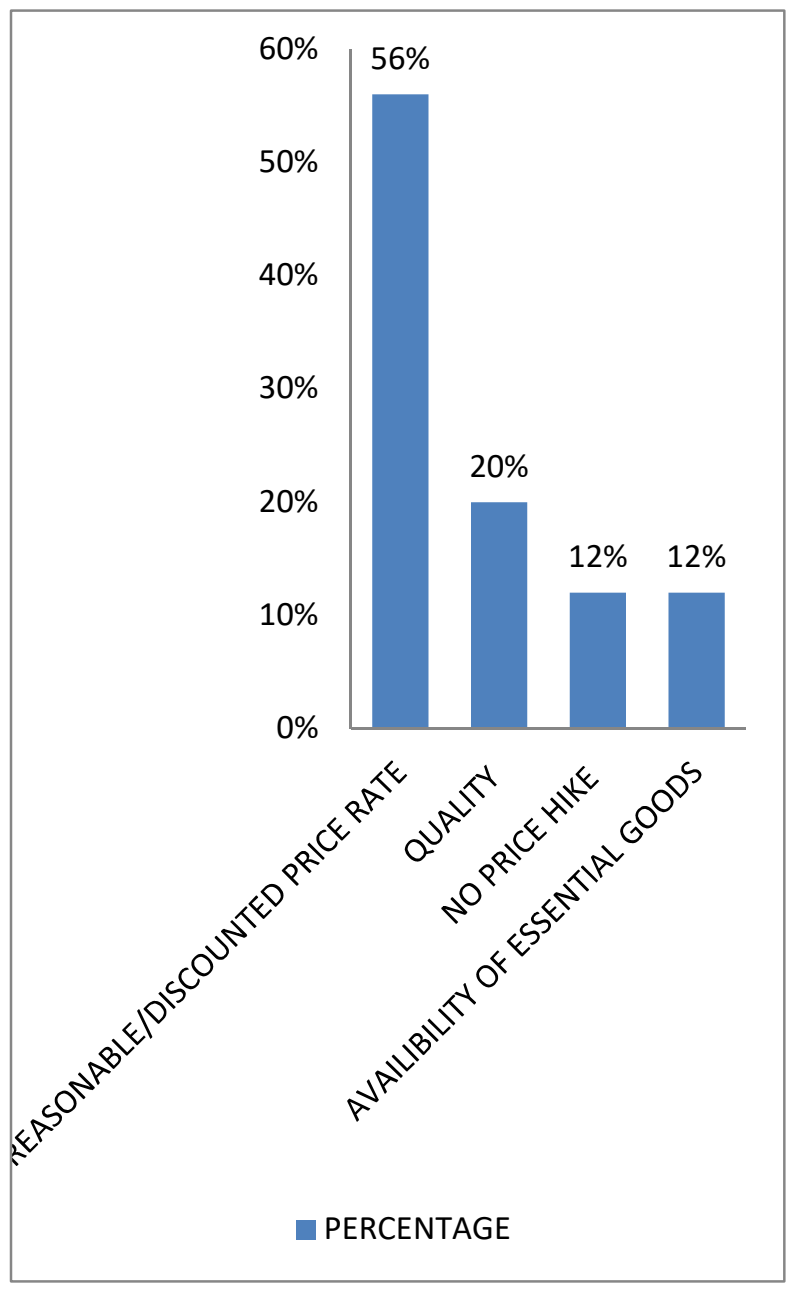

Source: Primary data/Schedules

The above table -8 and Figure -3 showing that the Reasonable or discounted price is the superior feature of govt. Controlled retail shops. Among the respondents $56 \%$ are under this category.

\section{TABLE - 9: Comparison between Maveli Store price and market price}

\begin{tabular}{|l|c|c|}
\hline \multicolumn{1}{|c|}{ Items } & $\begin{array}{c}\text { Maveli } \\
\text { store price }\end{array}$ & $\begin{array}{c}\text { Market } \\
\text { price }\end{array}$ \\
\hline Rice & 25 & 37 \\
\hline Jaya & 24.5 & 33 \\
\hline Kuruva & 23 & 26.5 \\
\hline Matta & & \\
\hline Pulses\&dals & 66 & 68 \\
\hline Green gram & 43 & 85 \\
\hline Bangal gram & 65 & 69 \\
\hline Mutter gram & 135 & 66 \\
\hline Urad dal & 66 & 35 \\
\hline Pigon gram & 75 & 101 \\
\hline Red chilly & 92 & 95 \\
\hline Coriander seed & 90 & 150 \\
\hline Coconut oil & 15 & 27 \\
\hline Atta & 38 & 44 \\
\hline Sugar & & 68 \\
\hline Others & & \\
\hline Goderage no.1 soap & & \\
\hline
\end{tabular}


International Journal of Trend in Scientific Research and Development (IJTSRD) ISSN: 2456-6470

\begin{tabular}{|c|c|c|}
\hline$(4 * 400)$ & & \\
\hline $\begin{array}{l}\text { Colgate dental cream } \\
(100 \mathrm{~g})\end{array}$ & 45.61 & 48 \\
\hline Sunlight(150g) & 17 & 18 \\
\hline $\begin{array}{l}\text { Ujala detergent powder } \\
(1 \mathrm{k.g})\end{array}$ & 75 & 79 \\
\hline $\begin{array}{l}\text { Wheel lemon powder } \\
(1 \mathrm{k.g})\end{array}$ & 49.5 & 52 \\
\hline Close up $(80 \mathrm{~g})$ & 44.66 & 47 \\
\hline Sunlight (1 k.g) & 74 & 78 \\
\hline Surf execel $(500 \mathrm{~g})$ & 54 & 57 \\
\hline Santoor soap (150g) & 36 & 38 \\
\hline Horlics oats $(1 \mathrm{k.g})$ & 180 & 190 \\
\hline Lux soap (100 g) & 24 & 26 \\
\hline Harpic liquid (500 mg) & 70.3 & 74 \\
\hline Vim bar(500 g) & 33 & 45 \\
\hline Pears soap (125 g) & 57 & 60 \\
\hline Boost (500 g) & 220 & 232 \\
\hline Britania good day & 33 & 35 \\
\hline Life boy soap & 23.7 & 26 \\
\hline $\begin{array}{l}\text { Swamis chili powder } \\
(250 \mathrm{~g})\end{array}$ & 56.25 & 59 \\
\hline
\end{tabular}

Source: secondary data/Price list of Supplyco Maveli Store.

\section{FINDINGS}

$>$ Majority of the respondents are under the category of Below Poverty Line.

$>$ The majority people are purchasing necessary goods from the Government controlled retailing outlets for their average monthly consumption.

$>$ The average income of the respondents is 27000

$>$ Most of the respondents are employed in the private sector

$>$ The average family size of the sample is 3 to 4 members

$>$ The superior feature of Supplyco Maveli Store is the discounted price rate.

$>$ The major part of the selected sample is having the relationship with the store more than 9 years.

$>$ The family size is a factor for the purchasing behavior of the respondents from the Maveli Stores.

Supplyco Maveli Store is able to meet the essential purchase requirements of the poor in the society.

There is an equal demand for the subsidized and non-subsidized products offered by the Maveli Store.

\section{SUGGESTIONS}

$>$ The important suggestion from the respondents is to increase the limit of purchase quantity of the subsidized goods.

Maintain a minimum stock level in every time, and then the difficulty of non-availability of goods will be reduced to an extent.

$>$ Develop an application system for Supply co Maveli Stores to spread the important information about the available stock and its prices.

Add more goods to the subsidized goods list.

\section{CONCLUSION}

The future of retailing seems to be bright with changing life styles, consumerism and increase in the disposable income of the people. Though, government controlled retailing system is spreading in various parts of the state, it is facing competition from innumerable number of small unorganized retailers. Government organized retailing has good prospectus among the people, but it has to face competition from traditional retailers local and private sector retailers. The better quality of the products and reasonable prices have attracted the all sections of the society to purchase essential goods from these Government controlled retailing system. But all sections of the society may not be able to purchase frequently from these shops, because the unavailability of goods at the needed time and the required quantity of goods from the Maveli stores, because of these reasons they shift the purchases from Maveli stores to the Traditional or local vendors. Moreover the poor have lower income to have frequent or bulk purchases. In this context, they rely upon the local vendors in their locality. The familiarity with the shopkeeper helps to gain the advantage of monthly credit. But these reasons are not reducing the demand for the Maveli Stores goods. The people have a loyalty towards the 
International Journal of Trend in Scientific Research and Development (IJTSRD) ISSN: 2456-6470

Government programs. The Government program of market intervention, pulses and spices are purchased and sold to the consumers at subsidized prices fixed by the Government .Consumers trusts Government. That's why SUPPLYCO Maveli Store plays an important role in retailing, most importantly among the poor people in Kerala. For meeting the essential needs of the consumers SUPPLYCO Maveli Stores throughout the state covering almost all the Panchayaths.

\section{REFERENCE}

Books

1. DR. N.K Sahni, ManiParty, 'Retail Management', Kalayani Publishers, Ludhiana, NewDelhi.

$>$ Websites

1. http://www.supplycokerala.com/mavelistore.htm

2. http://www.mavelistore.ca/

3. http://www.supplycokerala.com/labhamarkets.htm

4. http://www.businessdictionary.com/definition/retail ing.html

5. http://www.indiaretailing.com/

6. http://www.indianmba.com/occasional_papers/op99 /op99.html 